\title{
What if the 'Anthropocene' is not formalised as a new geological Series/Epoch?
}

\author{
Valentí Rull \\ Institute of Earth Sciences Jaume Almera, ICTJA, CSIC, C/ Solé i Sabarís, s/n, 08028 Barcelona, Spain
}

\begin{abstract}
In the coming years, the Anthropocene Working Group (AWG) will submit its proposal on the 'Anthropocene' as a new geological epoch to the International Commission on Stratigraphy (ICS) for approval. If approved, the proposal will be send to the International Union of Geological Sciences (IUGS) for ratification. If the proposal is approved and ratified, the 'Anthropocene' will be formalised and the Holocene Series/Epoch will be officially terminated. Currently, the 'Anthropocene' is a broadly used term and concept in a wide range of scientific and non-scientific situations and, for many, the official acceptance of this term is only a matter of time. However, the AWG proposal, in its present state, seems to not fully meet the ICS requirements for a new geological epoch. This paper asks what could happen if the current 'Anthropocene' proposal is not formalised by the ICS/IUGS. The possible stratigraphic alternatives are evaluated on the basis of the more recent literature and the personal opinions of distinguished AWG and ICS members. The eventual impact on environmental sciences and on non-scientific sectors, where the 'Anthropocene' seems already firmly rooted and de facto accepted as a new geological epoch, are also discussed.
\end{abstract}

Keywords: Anthropocene, Series/Epoch, chronostratigraphic units, formalization, Anthropocene Working Group

\section{Introduction}

In spite of its rather common usage in a wide array of scientific and non-scientific environments, the 'Anthropocene' is an informal term (this is why the quotation marks) whose formalisation process has not started yet. For this to occur, the first step is to assemble a proposal to be submitted to the International Commission on Stratigraphy (ICS) for approval. If approved, the proposal should be ratified by the International Union of Geological Sciences (IUGS). After this, the new unit can be incorporated to the International Chronostratigraphic Chart (ICC), which is the international stratigraphic reference and the basis for the geological time scale, one of the great achievements of humanity, comparable to the periodic table of elements [1]. For a new chronostratigraphic unit to be defined, it is necessary first to recognize and date its lower boundary on a particular rock sequence (the type section or stratotype) from a particular locality (the type locality) and to identify the particular rock features (the stratigraphic markers) that characterize such unit and differentiates it from the underlying one. This defines the Global boundary Stratotype Section and Point (GSSP) of the eventual new unit, which is required for a proposal to be submitted to the ICS. The proposed unit should be global and synchronous, that is, it should be recognisable worldwide and its lower boundary should have the same age everywhere [2].

Since 2009, the Anthropocene Working Group (AWG) has been working on the proposal about the 'Anthropocene' as a new series/epoch of the ICC following the Holocene. Details on the composition and activities of this task group can be seen in its website (http://quaternary.stratigraphy.org/workinggroups/anthropocene). To date, the AWG has preliminarily established the age for the beginning of the 'Anthropocene' and the better suited stratigraphic marker and now is working on the definition of the better suited stratotype and the corresponding GSSP [3]. In its present state, the proposal places the onset of the 'Anthropocene' epoch at the mid-20 ${ }^{\text {th }}$ century $(\sim 1950)$, coinciding with the Great Acceleration, and suggests that the plutonium $(\mathrm{Pu})$ fallout, originated by the first nuclear explosions, could be the best stratigraphic marker. According to the latest publications on the subject, the AWG estimates to have the proposal ready for submission by 2019 or 2020 [4]. However, the AWG Convenor, Jan Zalasiewicz, in a recent communication (27 September 2018), told the author of this paper that the project is very big and the final proposal may actually take more time. The approval process is complex and time consuming and involves several organization levels within the ICS, structured in a hierarchical manner. Proposals should be submitted first to the corresponding subcommission, in this case the Subcommission on Quaternary 
Stratigraphy (SQS) and, if approved, they move forward to the ICS Bureau. Approval by these two instances requires supermajority, as expressed in the positive votes of $>60 \%$ of their respective members after detailed analysis and discussion of the topic, which may involve a significant amount of time. Proposals that fail to achieve supermajority may be returned to the AWG for eventual reformulation, with the corresponding additional time and effort. If finally approved by the ICS, the proposal is submitted to the Executive Committee of the International IUGS for ratification, which is not automatic either and requires further scientific evaluation $[5,6]$. More detailed information on the official rules and the approval process can be found in the ICS website (http://www.stratigraphy.org).

The AWG is very active in the dissemination of its progresses on the definition and characterisation of the 'Anthropocene', which are frequently published in books [7] and journals, including high-impact multidisciplinary journals [8]. The AWG advances are commented on by other scholars, who agree or disagree with their propositions. Sometimes, the commentaries come from geologists who are members of the highest ICS and/or IUGS hierarchical levels [5,6,9], which could be useful to appreciate how the proposal is received at these decision stages and allows us to anticipate what would be the result of their deliberations, in the current situation. The latest publications of this type may suggest that, in its present form -that is, the mid-20th century as the 'Anthropocene' onset and the Pu fallout as the stratigraphic marker-the current AWG proposal might not be approved. Therefore, contrary to many expectations, the formalisation of the 'Anthropocene' does not seem to be merely a matter of time. The critiques emphasise some procedural flaws - notably that the 'Anthropocene' does not derive from a stratigraphic necessity, but from purely environmental considerations - and stratigraphic weaknesses -for example, the lack of a physical stratigraphic basis to represent an eventual 'Anthropocene' starting at $\sim 1950$-, as well as the fact that the interest on the formalisation of the 'Anthropocene' is not genuinely scientific but has political (environmental) motivations [9,10] or is a phenomenon of pop culture [11]. The AWG members have responded to these critiques but the basic elements of their proposal have been maintained $[12,13]$. The detailed arguments from both sides are beyond the aims of this paper, which is focused on what would happen if the AWG 'Anthropocene' proposal is finally rejected by the ICS/IUGS, a possibility that is rarely addressed.

\section{Stratigraphic alternatives}

First of all, it should be stressed that the AWG can still change or modify its current proposal. There are internal discussions to do so, as the current proposal ignores previous centuries or millennia of human interference in the Earth System $[14,15,16]$. The problem is that the onset of human influence has not been synchronous around the globe and, according to the current stratigraphic rules, a diachronic boundary is not acceptable for characterising a chronostratigraphic unit. There is also the possibility of defining a stratigraphic unit different from an epoch. For example, Philip Gibbard, the ICS Secretary-General, told the author that there are two other possibilities (23 September 2018, personal communication): (i) to define an Event or Episode or (ii) to define a subdivision of the Late Holocene Subseries/Subepoch, after the Meghalayan Stage, either as a stage/age or a chron. Gibbard also suggested the AWG to propose the definition of a GSSA (Global Standard Stratigraphic Age) instead a GSSP for the lower boundary, but the AWG remains attached to a GSSP. These possibilities would avoid conflict with a number of SQS members, especially those from the Holocene community, who are reluctant to accept that the Holocene ended with the Great Acceleration. According to the current stratigraphic rules, any of the above options require a term different from 'Anthropocene', as the termination '-cene' is reserved for the Cenozoic series/epochs [17].

Then, the AWG still has the option of downgrading its conceptual and stratigraphic perspectives to increase the approval chances or to remain attached to the current 'Anthropocene' definition, whose formalisation possibilities seem to be more reduced. In the second case, an eventual rejection by the ICS/IUGS would lead the AWG seriously to consider the first option, which will reset the process, with the corresponding additional time and effort. The main problem is that the alternatives mentioned above involve the downgrading of the current 'Anthropocene' concept to a stratigraphic unit within the Holocene and, hence, below the series/epoch rank. This challenges a fundamental tenet of the AWG, which is that the Holocene has been terminated and we are in a new geological epoch. This also challenges the conviction of many AWG members who defend that the 'Anthropocene' represents a new state of the biosphere after the microbian stage (of approximately 3 billion years duration, since the origin of life until the end of the 
Precambrian) and the metazoan stage (since the origin of the metazoans, approximately 0.7 billion years ago to the present) [18]. Merely a subdivision of the Late Holocene would hardly represent such telluric revolution. A third option, after eventual rejection, would be to abandon the venture of defining a new stratigraphic unit based on the human footprint on Earth. Neither the ICS nor the IUGS have responsibility for this (although they can recommend that course of action), only the SQS or the AWG can decide about resubmitting or not a new proposal (Gibbard, 23 September 2018, personal communication).

The author asked Jan Zalasiewicz about the possibility of an eventual plan B if the proposal is not approved and/or ratified, and he responded that: 'The plan A is always to do the best and most honest scientific job possible, and then see what happens. The long-term aim (whether the case is accepted/ratified or not) is to build up the science base so that the term can (whether formal or not) be more effectively used and understood, at least in a geological/Earth System science sense' (27 September 2018). Therefore, it seems clear that downgrading options will not be considered by the AWG. Some members of the IUGS Executive were also approached by the author for opinion but they did not answer or declined to comment the issue, arguing that, as members of the organization responsible for the final decision, they are not free to express their personal opinion on the subject, at this stage. The only general comment from a IUGS member who will remain anonymous was: "...the issue of the Anthropocene is getting out of hand: too much media hype, too little scientific reasoning".

\section{Beyond geology}

Strictly speaking, if the term 'Anthropocene' is not formalised, it should not be used but, in the words of Philip Gibbard (23 September 2018, personal communication), the ICS is not a police force and cannot stop people using terms. In addition, the term is firmly rooted in many professional and public environments even in renowned dictionaries (Oxford, Cambridge, Collins, Merriam-Webster, MacMillan)- and, according to Ruddiman et al. [19], the term 'Anthropocene' is here to stay. Due to its environmental connotations - we should not forget that the term was coined by an environmental chemist (Paul Crutzen) and an ecologist (Eugene Stoermer) on the basis of environmental criteria [20]- this term has been especially successful in the fields of ecology, conservation and environmental sciences, in general, where it has been de facto adopted by many as a new geological epoch without waiting for its eventual formalisation. Currently, there are three scientific journals with the word Anthropocene (without quotes) in their titles, namely The Anthropocene (Elsevier), The Anthropocene Review (SAGE) and Elementa: Science of the Anthropocene (Univ. of California Press). The term is also profusely used in scientific books and articles without quotation marks, as if it was already formalised. The same is true in a wide array of disciplines apart from natural sciences, where the 'Anthropocene' is used for a variety of purposes beyond its genuine stratigraphic meaning. For example, in philosophical, political and economic terms, the 'Anthropocene' has been considered an expression of modernity, an attack to the Earth System or a dystopian end of humanity, an assault to human rights, an outgrowth of capitalism, an excess of consumerism, the definitive decoupling between human welfare and environmental impacts or an ethical and biological imperative, among others [21].

The author is not fully aware of the different 'Anthropocene' meanings used in non-scientific disciplines but, recently, he has a very illustrative experience in this sense in a seminar celebrated in the Autonomous University of Madrid (Spain), where he was invited to give a talk on the scientific bases of the 'Anthropocene'. The audience was composed mainly of philosophers, sociologists, anthropologists, historians, politicians, ecological activists, poets and artists, as well as some scientists unfamiliar with geology and earth sciences, in general. The feedback received from this public may be summarised into three main points. One of the participants commented that it does not matter whether geologists officially formalise or not the 'Anthropocene' as a new epoch, the term will keep being used. Another member of the audience wondered about what is the interest of a number of geologists in defining a new stratigraphic unit and what could this be useful for. Another participant asked why not using a different term, devoid of any stratigraphic connotation, as for example the Great Acceleration, simply to describe a new historical phase in the human-Earth relationships,. These are recurrent and unsolved scientific questions that emerged from a mostly non-scientific but enlightened and open-minded audience, which suggests that these points are not trivial and are general enough to be seriously considered. 
Regarding the first point, it seems clear that the preliminary definition by Crutzen and Stoermer [20] of the 'Anthropocene' as a new geological epoch, characterised by the human footprint on Earth, is enough in most non-scientific sectors (and also in scientific ones, especially in environmental sciences), where there is no concern about further ICS/IUGS scientific formalization. The second point, the interest of a number of scientists in formalising the 'Anthropocene' seems to obey to the conviction that there is sufficient stratigraphic basis for it to be considered a new geological series/epoch. In addition, a number of geologists favour such formalisation because they believe that official recognition of human impact of Earth System could make the society and governments aware of such situation, which could facilitate preventive and corrective actions. The third point, that is, choosing a different name devoid of stratigraphic significance, i.e. without terminations such as '-cene', -zoic' or '-gene', has also been proposed in the scientific literature but this option is rarely considered [17].

\section{Does formalisation matter?}

It seems clear that formalisation only matters for a number of geologists, particularly stratigraphers. For non-geologists, formalisation seems not to be relevant and the term is freely used, usually without brackets, with a variety of meanings, mostly with evident environmental and historical connotations. Therefore, it seems that the formalization or not of the 'Anthropocene' is irrelevant for most scientific and non-scientific sectors and the term will probably remain in the quotidian life with a diffuse meaning, depending on the preferences of each particular user. Scientific questions should be addressed using rigorous scientific methods, rather than wide consensus involving scientific and non-scientific sectors. In the case of the 'Anthropocene', the discipline that matters is stratigraphy, not environmental or historical sciences, and the issue is in the hands of the AWG and the ICS/IUGS, whose final decision should be universally accepted and implemented. If the 'Anthropocene' is finally formalised, the Holocene will be terminated and a new epoch will have started. However, if it is not formalised, the term should be abandoned. There are numerous alternative terms, without stratigraphic meaning, that could be used. It would be illustrative to compare this situation with the hypothetical case of an eventual proposal for a new element of the periodic table, let us say the 'anthroponium', whose formalisation corresponds to the International Unions of Pure and Applied Physics and Chemistry (IUPAP/IUPAC). It could be asked whether non-chemical/physical scientists and non-scientists would be as careless as they are in the case of the 'Anthropocene' and how could they behave if the IUPAP/IUPAC finally decided that the 'anthroponium' did not qualify as a new element of the periodic table because it is actually, let us say, a carbon isotope. Certainly, the 'anthroponium' term and concept would be abandoned. A similar example could be found in language if a word is not accepted by the corresponding academy as a valid term to be included in the dictionary. Why should the case be different with the 'Anthropocene'?

From an environmental perspective, the issue of the human influence in the Earth's System and the actions needed to redress the situation will not change whether the term 'Anthropocene' is formalised or not. The 'Anthropocene' is strictly a stratigraphic term and the issue of its formalisation as a new chronostratigraphic unit should be disentangled from any environmental, philosophical, sociological, political or economic considerations [22]. Obviously, the 'Anthropocene' term and concept have implicit environmental connotations that cannot be ignored, but this could not form the basis for the formalisation of a new chronostratigraphic unit of the ICC. It will be interesting to follow the progress of the AWG proposal and the further discussions within the ICS and the IUGS, to realise whether or not we can freely use the term 'Anthropocene' without apostrophes or we should remove it from our dictionaries. Formalisation matters, not only in physics, chemistry or language but also in geology.

\section{Acknowledgements}

The author is grateful to Philip Gibbard and Jan Zalasiewicz for sharing their views on the 'Anthropocene' formalisation and usage and for providing feedback on the first draft of the manuscript. Other ICS and IUGS members who have preferred to remain anonymous are also acknowledged. 


\section{References}

1. Monastersky, R. Anthropocene: the human age. Nature 2015, 519, 144-147.

2. Salvador, A. International stratigraphic guide. A guide to stratigraphic classification, terminology, and procedure; Geological Society of America: Boulder, Colorado, 2013; 214 p.

3. Waters, C.M.; Zalasiewicz, J.; Summerhayes, C.P.; Fairchild, I.J.; Rose, N.L.; Loader, N. J.; Shotyk, W.; Cearreta, A.; Head, M.J.; Syvitski, J.P.M.; et al. Global Boundary Stratotype Section and Point (GGSP) for the Anthropocene Series: where and how to look for potential candidates. Earth-Sci. Rev. 2018, 178, 379-429.

4. Zalasiewicz, J.; Waters, C.N.; Summerhayes, C.P.; Wolfe, A.P.; Barnosky, A.D.; Cearreta, A.; Crutzen, P.; Ellis, E.; Fairchild, I.J.; Gałuszka, A.; et al. The Working Group on the Anthropocene: summary of evidence and interim recommendations. Athropocene 2017, 19, 55-60.

5. Finney, S.C. The 'Anthropocene' as a ratified unit of the ICS International Stratigraphic Chart: fundamental issues that must be addressed by the Task Group. In A stratigraphical basis for the Anthropocene; Waters, C.N.; Zalasiewicz, J.A.; Williams, M.; Ellis, M.A.; Snelling, A.M., Eds.; The Geological Society of London, London, UK, 2014; pp. 23-28.

6. Gibbard, P.L.; Walker, M.J.C. The term 'Anthropocene' in the context of formal geological classification. In A stratigraphical basis for the Anthropocene; Waters, C.N.; Zalasiewicz, J.A.; Williams, M.; Ellis, M.A.; Snelling, A.M., Eds.; The Geological Society of London, London, UK, 2014; pp. 29-37.

7. Waters, C. N., Zalasiewicz, J. A., Williams, M., Ellis, M. A. \& Snelling, A. M. (2014) A stratigraphical basis for the Anthropocene. London: The Geological Society of London.

8. Waters, C.N.; Zalasiewicz, J.; Summerhayes, C.P.; Barnosky, A.D.; Poirier, C.; Gałuszka, A.; Cearreta, A.; Edgeworth, M.; Ellis, E.C.; Ellis, M.; et al. The Anthropocene is functionally and stratigraphically distinct from the Holocene. Science 2016, 351, aad2622-1-aad2622-10.

9. Finney, S.C.; Edwards, L.E. The "Anthropocene" epoch: scientific decision or political statement? GSA Today 2015, 26, 4-10.

10. Edwards, L.E. What is the Anthropocene? EOS 2015, 96: 6-7.

11. Autin, W.J.; Holbrook, J.M. Is the Anthropocene an issue of stratigraphy or pop culture? GSA Today 2012, 22, 60-61.

12. Zalasiewicz, J.; Waters, C.N.; Wolfe, A.P.; Barnosky, A.D.; Cearreta, A.; Edgeworth, M.; Ellis, E.C.; Fairchild, I.; Gradstein, F.M.; Grinevald, J.; et al. Finney and Edwrads article. GSA Today 2016, 27, e36-e37.

13. Zalasiewicz, J.; Waters, C.N.; Wolfe, A.P.; Barnosky, A.D.; Cearreta, A.; Edgeworth, M.; Ellis, E.C.; Fairchild, I.J.; Gradstein, F.M.; Grinevald, J.; et al. (2017b) Making the case for a formal Anthropocene Epoch: an analysis of the ongoing critiques. Newsl. Stratigr. 2017, 50, 205-226.

14. Ruddiman, W.F. The Anthropocene. Ann. Rev. Earth Planet. Sci. 2013, 41, 45-68.

15. Lewis, S.L.; Maslin, M.A. Defining the Anthropocene. Nature 2015, 519, 171-180.

16. Ellis, E.; Maslin, M.; Boivin, N.; Bauer, A. Involve social scientists in defining the Anthropocene. Nature 2016, 540, 192-193.

17. Rull, V. The Humanized Earth System (HES). Holocene 2016, 26, 1513-1515.

18. Williams, M.; Zalasiewicz, J.; Haff, P.K.; Schwägerl, C.; Barnosky, A.D.; Ellis, E.C. The Anthropocene biosphere. Anthropocene Rev. 2015, 2, 196-219.

19. Ruddiman, W.F.; Ellis, E. C.; Kaplan, J.O.; Fuller, D.Q. Defining the epoch in which we live. Is a formally designated Anthropocene a good idea? Science 2015, 348, 38-39.

20. Crutzen, P.J.; Stoermer, E.F. The 'Anthropocene'. IGBP Newsl. 2000, 41, 17-18.

21. Autin, W.J. Multiple dichotomies of the Anthropocene. Anthropocene Rev. 2016, 3, 218-230.

22. Rull, V. A futurist perspective on the Anthropocene. Holocene 2013, 23, 1198-1201. 